\title{
Hemşirelik İntörn Öğrencilerinin COVID-19 Şüpheli Çocuk Hasta İçin Belirledikleri Hemşirelik Tanılarının İncelenmesi
}

\section{Examination of Nursing Diagnosis Determined by Nursing Intern Students for COVID-19 Suspected Pediatric Patient}

\author{
Sibel Serap Ceylan ${ }^{1}$ (D) Türkan Turan ${ }^{1}$ (D) Çiğdem Erdoğan ${ }^{1}$ \\ ${ }^{1}$ Pamukkale Üniversitesi Sağlık Bilimleri Fakültesi, Cocuk Sağlığı ve Hastalıkları Hemşireliği Anabilim Dalı, Denizli, TÜRKIYE \\ Geliş tarihi/ Date of receipt: 02/03/2021 Kabul tarihi/ Date of acceptance: 06/08/2021 \\ (C) Ordu University Faculty of Health Sciences, Department of Nursing, Turkey, Published online: 26/12/2021
}

\section{ÖZ}

Amaç: Bu araştırma hemşirelik intörn öğrencilerinin COVID-19 şüphesi olan çocuk hasta ile ilgili verilen örnek vakada belirledikleri hemşirelik tanılarının incelenmesi amacıyla yürütülmüştür.

Yöntem: Bu araştırma tanımlayıcı türdedir. Araştırmaya bir üniversitenin hemşirelik bölümüne devam eden ve Çocuk Sağlığı ve Hastalıkları Hemşireliği İntörn Uygulama dersine kayıtlı öğrenciler alınmıştır. Araştırmada örneklem seçimine gidilmemiş, derse kayıtlı 80 öğrencinin belirlediği toplam 446 adet hemşirelik tanısı incelenmiştir. Öğrencilerin belirledikleri hemşirelik tanıları araştırmacılar tarafından NANDA (North American Nursing Diagnosis Association) hemşirelik tanıları sınıflandırma sisteminde bulunup bulunmaması, tanı yapısının ve belirlenen tanılarının COVID-19 şüpheli çocuk hasta için uygunluğu açısından değerlendirilmiştir.

Bulgular: Araştırmada her bir öğrenci ortalama 5.57 \pm 1.67 adet tanı belirlemiştir. Öğrencilerin belirledikleri tanıların; \%76.90’ının NANDA sınıflandırma sisteminde yer aldığı, \%35.20'sinde ilişkili faktör belirtildiği ve \%13.41'inde tanımlayıcı özellik belirtildiği bulunmuştur. Öğrencilerin belirlediği hemşirelik tanıları incelendiğinde çoğunluğunun sırasıyla hipertermi (\%14.87), etkisiz solunum örüntüleri (\%14.58), enfeksiyon riski (\%7.87), gaz değişiminde bozulma (\%6.71) ve anksiyete (\%6.41) olduğu görülmüştür.

Sonuç: Bu araştırmada öğrencilerin belirledikleri hemşirelik tanılarının çoğunluğunun COVID-19 şüpheli çocuğun bakımına uygun olduğu görülmüştür. Ancak tanıların çoğunluğu NANDA sınıflandırma sisteminde yer alsa da hemşirelik tanı yapıları incelendiğinde çoğunluğunda ilişkili faktör ve tanımlayıcı özellik bulunmamaktadır.

Anahtar kelimeler: COVID-19, çocuk, hemşirelik tanısı, hemşirelik öğrencisi

\begin{abstract}
Objective: This study was conducted to examine nursing diagnoses determined by nursing interns for sample case given about a pediatric patient with suspected COVID-19.

Methods: This study was descriptive. Students enrolled in Pediatric Nursing Internship Practice course, attending the nursing department of a university, were included in the study. Sample selection was not made in the study, and a total of 446 nursing diagnoses determined by 80 students enrolled in the course were examined. The nursing diagnoses determined by the students were evaluated by the researchers in terms of whether they were in NANDA nursing diagnoses classification system, and diagnostic structure and diagnoses were appropriate for COVID-19 suspected pediatric patient.

Results: In the study, each student identified an average of $5.57 \pm 1.67$ diagnoses. It was found that $76.90 \%$ of the diagnoses determined by the students were included in NANDA classification system, 35.20\% indicated the related factor, and $13.41 \%$ indicated a descriptive feature. When the nursing diagnoses determined by the students were examined, it was observed that the majority of them had hyperthermia $(14.87 \%)$, ineffective respiratory patterns (14.58\%), infection risk $(7.87 \%)$, gas exchange disruption $(6.71 \%)$, and anxiety $(6.41 \%)$, respectively.

Conclusion: In this study, it was observed that most of nursing diagnoses determined by the students were suitable for the care of the pediatric patient suspected of Covid-19. However, although most of the diagnoses are included in NANDA classification system, when the nursing diagnosis structures are examined, most of them do not have related factors and descriptive features.

Keywords: COVID-19, child, nursing diagnosis, nursing student

ORCID IDs of the authors: SSC: 0000-0001-6672-1749; TT: 0000-0002-8427-672X; CE: 0000-0003-0367-6981

Sorumlu yazar/Corresponding author: Öğr. Gör. Dr. Sibel Serap Ceylan

Pamukkale Üniversitesi Sağlık Bilimleri Fakültesi, Cocuk Sağıı̆̆ı ve Hastalıkları Hemșireliği Anabilim Dalı, Denizli, TÜRKIYE

e-posta/e-mail: ssceylan@pau.edu.tr; sibelserap@gmail.com

*Bu çalışma 15-20 Aralık 2020 tarihlerinde düzenlenen 64.Türkiye Milli Pediatri Kongresi, 19. Milli Çocuk Hemşireliği kongresinde poster bildiri olarak sunulmuștur.

Atıf/Citation: Ceylan SS, Turan T, Erdoğan Ç. (2021). Hemşirelik İntörn Öğrencilerinin COVID-19 Şüpheli Çocuk Hasta İçin Belirledikleri Hemșirelik Tanılarının İncelenmesi. Ordu Üniversitesi Hemșirelik Çalıșmaları Dergisi, 4(3), 349-356. DOI: 10.38108/ouhcd.889704
\end{abstract}




\section{Giriş}

COVID-19, Çin'in Wuhan şehrinde 2019 y1lı Aralık ayında ortaya çıkan ve kısa sürede tüm dünyaya yayılan, şiddetli akut solunum sendromu ve pnömoniye neden olan bir virüstür (Huang ve ark., 2020; She ve ark., 2020a). Çocuklarda COVID-19 enfeksiyonu vaka ve mortalite oranları düşük olsa da çocuk sağlığı için önemli bir risktir. Çünkü çocuklarda ciddi ve kronik hastalıkların varlığı COVID-19 için risk oluşturmakta (Centers for Disease Control and Prevention, 2020), toplumsal bulaşda çocuklar önemli rol oynamakta (Cao ve ark., 2020; Hagmann, 2020), çocukların eğitimi ve psikolojik durumu etkilenmektedir (Akoğlu ve Karaaslan, 2020). COVID-19'un çocuklara bulaşma yolu ve enfeksiyon bulguları yetişkinler ile aynıdır (Centers for Disease Control and Prevention, 2020). Virüslerin çocuğa bulaşması çoğunlukla aile içi temas ile gerçekleşmektedir (She ve ark., 2020 b). COVID-19 enfeksiyonu çocuklarda belirti ve bulgu göstermeden seyredebileceği gibi semptom gösteren vakalarda da ateş, kuru öksürük, yorgunluk ve baş ağrisına rastlanmaktadır (Lu ve Shi, 2020). Ayrica çocuklarda burun tıkanıklığı, burun akıntısı, mide bulantıs1, kusma ve ishal bulguları da görülebilmektedir. Çocuklar hastalığı çoğunlukla hafif semptomlarla geçirmesine rağmen ateş veya pnömoni enfeksiyon hastalığının prognozunu kötüleştirmektedir (She ve ark., 2020b; Ludvigsson, 2020).

COVID-19 pandemisi hemşirelik bakımını ön plana çıkarmıştır (Türk Hemşireler Derneği, 2020). Bununla birlikte hemşirelerin çocuklarda COVID19 enfeksiyonunun önlenmesi, kontrolü, hasta çocukların tedavi ve bakım sürecinde, çocukların ruh sağ 1 ğının korunması ve geliştirilmesinde görev ve sorumlulukları bulunmaktadır. COVID-19 şüphesi veya tanısı olan çocuklarda hemşirelik bakımı hedefleri şunlardır: enfeksiyonun yayılmasını önlemek, yeterli kalori ve sıvı alımını desteklemek, sivi-elektrolit dengesini korumak, homeostazisi sürdürmek ve destekleyici bakımın verilmesidir (Pars, 2020). Bu hedeflere ulaşmak için hemşirelik sürecinin iyi bir şekilde yönetilmesi gerekmektedir. Hemşireler birey, aile ve toplumun tüm bakım ortamlarında hemşirelik bakımını düzenlemek için sistematik bir yaklaşım olan hemşirelik sürecini kullanmaktadırlar (Birol, 2013). Dünya Sağl1k Örgütü (DSÖ) hemşirelik sürecini, hemşirelik bakımında bilimsel problem çözümleme yönteminin sistemli bir biçimde kullanılması olarak tanımlamıştır (World Healt Organization, 2009).
Türkiye'de Hemşirelik Kanununa göre, hemşireler uygulamalarında hemşirelik sürecini temel almalıdırlar (Türk Hemşireler Derneği, 2007). Hemşirelik süreci, verilerin toplanması, hemşirelik tanısının koyulması, sonuç kriterlerinin belirlenmesi, planlama, uygulama ve değerlendirme aşamalarını içermektedir. Hemşirelik tanısı birey, aile ve toplumun var olan ya da olası sağlık problemlerine verdiği yanıta odaklanmaktadır (Birol, 2013). Çocuk ve ailesinin hemşirelik probleminin başarı ile çözümlenmesi hemşirelik tanısının doğru belirlenmesine bağlıdır. Toplanan veriler adlandırılamaz ise kullanılamaz. $\mathrm{Bu}$ nedenle tanı belirleme sürecinde hemşirenin bilgi, deneyimi eleştirel düşünme ve sentez etme becerisi önemlidir (Ak, 2013). Kuzey Amerikan Hemşirelik Tanıları Birliği (NANDA) hemşirelik tanıları en yaygın kullanılan hemşirelik tanıları sınıflama sistemidir. Standardize edilmiş hemşirelik tanılama sistemleri hastaya uygun sonuçların belirlenme, hemşirelik girişimlerine karar verme, bilgiyi düzenleme ve paylaşmada profesyonel ve ortak bir dil kullanılmasinı sağlamaktadır (Rabelo-Silva ve ark., 2020). Ayrıca COVID-19 pandemisi gibi ani ve beklenmedik salgınlar ile savaşta sunulan sağlık hizmetinin daha kaliteli ve güvenli olması için hemşirelere güncel bilgi ve yol haritalarına gereksinim vardır. Yapılan çalışmalarda COVID-19 enfeksiyonu olan hasta için belirlenmiş hemşirelik tanıları Tablo 1'de verilmiştir (Moorhead ve ark. 2020; Sukmana ve Yuniarti, 2020; Queiroz ve ark., 2020; González-Aguña ve ark., 2020; Swanson ve ark., 2020).

Hemşirelik süreci eğitimi öğrencilere lisans eğitimleri sırasında ilk yıldan itibaren verilmektedir. Hemşirelik sürecinin lisans eğitiminde kullanılması ile birlikte öğrencilerde profesyonelleşmenin gelişimine, hemşirelik ile ilgili kavramların benimsenmesine ve hasta bakımının rahatlıkla uygulamasına firsat verilmektedir (Özveren ve ark., 2019). Bununla birlikte hemşirelik süreci, hemşirelik öğrencilerine bilimsel problem çözmeyi de öğretmektedir. Öğrenci hemşirelik tanısını belirleyerek klinik karar verme, sağllğı tanılama ve bilgileri entegre etme becerilerini de geliştirmektedir (Popil 2011). Ancak hemşirelik öğrencileri hemşirelik sürecini kullanmada bazı sorunlarla karşılaşabilmektedirler. Yapılan çalışmalar öğrencilerin yaşadığ 1 sorunun genellikle hemşirelik tanılarının belirlenmesi aşamasında olduğunu göstermektedir (Yılmaz ve 
ark., 2019; Keski ve Karadağ, 2010; Hakverdioğlu ve ark., 2014). Bu nedenle uluslararası hemşirelik tanılama sistemlerinden biri olan NANDA gibi tanılama sistemleri hasta verilerini görünür kılması ve bakım sonuçlarının takip edilmesi açısından hemşirelik öğrencileri için önemli bir rehberdir (Rabelo-Silva ve ark., 2020). Öğrencilerin mezuniyet sonrasında hemşirelik sürecini doğru ve etkili bir șeklide kullanabilmeleri için lisans eğitiminde de klinik uygulamalarda hemşirelik sürecini doğru ve etkili kullanmaları gerekmektedir (Şendir ve ark., 2014). Özellikle eğitimlerinin son yılında olan intörn hemşirelik öğrencilerinin hasta bakımında hemşirelik tanılaması yapabilmelerine firsat verilmesi ve becerilerinin değerlendirilmesi önemlidir. Çünkü intörnlüğün amacı öğrencilerin ilk üç yılda kazandıkları bilgi ve becerileri sağlık kurumlarında uygulayıp pekiştirmelerini sağlamak, karar verme becerilerini geliştirmek ve mezuniyet öncesinde mesleki deneyim kazanmalarına firsat vermektir (Bahçecioğlu ve ark., 2017).

$\mathrm{Bu}$ araştırmanın amacı hemşirelik intörn öğrencilerinin Covid-19 şüphesi olan çocuk hasta ilgili belirledikleri hemşirelik tanılarını hasta için uygun olup olmadığını ve tanı yapısında olması gereken özelliklerin bulunup bulunmamasına göre incelemektir.

\section{Gereç ve Yöntem}

\section{Araştırmanın evren ve örneklemi}

Tanımlayıcı türdeki araştırmaya bir üniversitenin hemşirelik bölümünde öğrenim gören son sinıf öğrencilerinden Çocuk Sağlığı ve Hastalıkları Hemşireliği İntörn Uygulama dersine kayıtlı öğrenciler alınmıştır. Örneklem seçimine gidilmeyip derse kayıtlı 80 öğrencinin COVID-19 şüpheli çocuk hasta için belirlediği toplam 446 adet hemşirelik tanısı incelenmiştir. Veriler HaziranTemmuz 2020 tarihlerinde toplanmıştır.

\section{Verilerin toplanması}

Pandemi sürecinde yükseköğretim kurumunun kararı ile yüz yüze eğitime ara verilmiş ve online eğitime geçilmiştir. $\mathrm{Bu}$ nedenle araştırmanın verileri ilgili üniversitenin online ders sistemi üzerinden toplanmıştır.

Araştırmada öğrencilere COVID-19 şüphesi olan çocuk ile ilgili bir vaka yazılı olarak verilmiştir. Literatür doğrultusunda hazırlanan örnek vakada yer alan hastanın özellikleri şunlardır: Hasta 13 yaşında olup ateş, öksürük ve solunum sıkıntısı şikayetleri bulunmaktadır (Bialek ve ark., 2020). Öğrencilerden verilen özellikler doğrultusunda literatür araştırması yapmaları ve
NANDA hemşirelik sinıflandırma sistemini kullanarak en az 5 tane hemşirelik tanısı belirlemeleri istenmiştir. Öğrenciler belirledikleri tanıları bilgisayar ortamında yazmışlar ve online ders sistemine word ya da pdf formatında dosya olarak yüklemişlerdir. Araştırmacılar öğrencilerin belirledikleri tanıları sistem üzerinden Hemşirelik tanılarını değerlendirme formunu kullanarak değerlendirmişlerdir.

\section{Veri toplama formları}

Hemşirelik tanılarını değerlendirme formu: $\mathrm{Bu}$ form öğrencilerin belirledikleri hemşirelik tanılarını NANDA hemşirelik taksonomisine uygunluğunu değerlendirmek ve tanı yapısını incelemek için araştırmacılar tarafından literatür doğrultusunda hazırlanmıştır (Birol, 2013; RabeloSilva ve ark., 2020; Carpenito-Moyet, 2012). Formda öğrencilerin koyduğu her bir hemşirelik tanısını değerlendirmeye yönelik 6 madde (hemşirelik tanısının adı, NANDA sınıflama sisteminde yer alma durumu, ilişkili faktörlerin belirtilmesi ve uygunluğu, tanımlayıcı özelliklerin belirtilmesi ve uygunluğu) bulunmaktadır.

\section{Verilerin analizi}

Araştırma elde edilen veriler PASW18 istatistik programında değerlendirilmiştir. Verilerin analizinde betimleyici analizlerden sayı, yüzde ve ortalama kullanılmıştır.

\section{Araştırmanın etik yönï}

Araştırmanın yürütülmesi için öncelikle T.C. Sağlık Bakanlığı COVID-19 Hastalığı Bilimsel Araştırmaları Platformundan ve ilgili üniversitesinin girişimsel olmayan klinik araştırmalar etik kurulundan onay alınmıştır (10 Haziran 2020 tarih ve 60116787-020/34110 say1). Etik kurul onayından sonra ilgili fakültenin dekanlığından yazılı izin alınmıştır.

\section{Bulgular}

Araştırmada öğrencilerin kişi başı ortalama $5.57 \pm 1.67$ adet hemşirelik tanısı belirlediği bulunmuştur. Öğrencilerin belirledikleri tanıların \%76.90'1 NANDA siniflandırma sisteminde yer almaktadır. Belirlenen hemşirelik tanılarının \% 35.20'sinde ilişkili faktör belirtildiği ve ilişskili faktörlerin \%96.20'sinin uygun olduğu bulunmuştur. Hemşirelik tanılarının \%73.54'ünde tanımlayıcı özellik belirtilmesi gerektiği ve tanıların \%13.41'inde tanımlayıc1 özellik belirtildiği saptanmıştır. Öğrencilerin belirlediği hemşirelik tanılarında yer alan tanımlayıcı özelliklerin \%97.72'sinin uygun olduğu görülmektedir (Tablo 2). 
Tablo 1. COVID-19 tanılı hasta için belirlenmiş hemşirelik tanıları

\begin{tabular}{|c|c|}
\hline \multicolumn{2}{|c|}{ NANDA sınıflandırma sisteminde yer alan tanılar } \\
\hline Alanlar & Tanı \\
\hline \multirow[t]{2}{*}{ Sağlığın yükseltilmesi } & Etkisiz korunma \\
\hline & Sağlığ1 Yönetmede etkisizlik:Toplum \\
\hline \multirow[t]{5}{*}{ Beslenme } & S1v1 volüm dengesizliği riski \\
\hline & $\begin{array}{l}\text { Beslenmede dengesizlik:Gereksinimden } \\
\text { az beslenme }\end{array}$ \\
\hline & Sıv1 volüm fazlalığ \\
\hline & Kan glikozunda değişkenlik riski \\
\hline & Sıv1 volüm dengesizliği riski \\
\hline \multirow{4}{*}{$\begin{array}{l}\text { Boşaltım ve gaz } \\
\text { değișimi }\end{array}$} & Gaz değişiminde bozulma \\
\hline & Üriner boşaltımda bozulma \\
\hline & Fonksiyonel inkontinans \\
\hline & Diyare \\
\hline \multirow[t]{9}{*}{ Aktivite/dinlenme } & Etkisiz solunum örüntüsü \\
\hline & Fiziksel mobiliditede bozulma \\
\hline & Aktivite intoleransı \\
\hline & Kardiyak out putta azalma riski \\
\hline & Kardiyak aut putta azalma \\
\hline & Spontane solunumda bozulma \\
\hline & $\begin{array}{l}\text { Ventilatörden ayrılamaya disfonksiyonel } \\
\text { tepki }\end{array}$ \\
\hline & Etkisiz periferik doku perfüzyonu \\
\hline & Etkisiz renal perfüzyon riski \\
\hline \multirow[t]{3}{*}{ Bilişsel-Algısal } & Sözel iletişimde bozulma \\
\hline & Bellekte bozulma \\
\hline & Akut konfüzyon \\
\hline \multirow[t]{2}{*}{ Kendini algılama } & Bilgi eksikliği \\
\hline & İnsan itibarının tehlikeye girmesi riski \\
\hline \multirow{7}{*}{$\begin{array}{l}\text { Baş etme/stres } \\
\text { toleransı }\end{array}$} & Anksiyete \\
\hline & Korku \\
\hline & Etkisiz toplumsal başetme \\
\hline & Ölüm anksiyetesi \\
\hline & Etkisiz baş etme \\
\hline & Otonomik disrefleksi riski \\
\hline & Otonomik disrefleksi \\
\hline \multirow[t]{17}{*}{ Güvenlik/korunma } & Enfeksiyon riski \\
\hline & Hipertermi \\
\hline & Kanama riski \\
\hline & Basınç yarası riski \\
\hline & Düşme riski \\
\hline & Oral mukoz membranda bozulma \\
\hline & Doku bütünlüğünde bozulma \\
\hline & Aspirasyon riski \\
\hline & Kontaminasyon \\
\hline & Kontaminasyon riski \\
\hline & Şok riski \\
\hline & Etkisiz termoregülasyon \\
\hline & Etkisiz hava yolu temizliği \\
\hline & Deri bütünlüğünde bozulma \\
\hline & Deri bütünlüğünde bozulma riski \\
\hline & Cerrahi iyileşmede gecikme \\
\hline & Vücut sıcaklığı dengesizliği riski \\
\hline \multirow[t]{3}{*}{ Konfor } & Akut ağrı \\
\hline & Konforda bozulma \\
\hline & Sosyal izolasyon \\
\hline \multicolumn{2}{|c|}{ NANDA sınıflandırma sisteminde yer almayan tanılar } \\
\hline & Vücut sıcaklığında dengesizlik riski \\
\hline & Öz-bakım eksikliği \\
\hline & $\begin{array}{l}\text { Bağışıklık sistemini güçlendirmeye hazır } \\
\text { olus }\end{array}$ \\
\hline & Hava yolu açıklığı etkisizdir \\
\hline & Spontan dolaşım bozuklukları riski \\
\hline
\end{tabular}

Tablo 3'te öğrencilerin NANDA siniflandırma sistemine uygun belirledikleri hemşirelik tanıları yer almaktadır. Öğrencilerin belirlediği en sık konulan tanılar şunlardır: hipertermi (\%14.87), etkisiz solunum örüntüleri (\%14.58), enfeksiyon riski (\%7.87), gaz değişiminde bozulma (\%6.71) ve anksiyete (\%6.41) olduğu görülmüştür.

Ayrıca öğrenciler rol ve ilişkiler boyutu ile ilgili olarak da aile içi süreçlerin devamlılığında bozulma (\%3.50) ve ebeveyn çocuk bağl1lığında bozulma riski $(\% 0.58)$ tanılarını belirlemişlerdir. Öğrencilerin belirlediği NANDA sinıflandırma sisteminde yer almayan tanılar incelendiğinde çoğunluğunun sırasıyla enfeksiyon bulaştırma riski (\%46.60), enfeksiyon (\%22.33), solunum fonksiyonunda bozulma riski (\%7.77) olduğu saptanmıştır (Tablo 4).

Tablo 2. Öğrencilerin COVID-19 şüpheli pediatrik hasta için belirledikleri hemşirelik tanılarının özellikleri $(\mathrm{n}=446)$

\begin{tabular}{lcc}
\hline Özellikler & n & \% \\
\hline NANDA sinıflandırma sisteminde & & \\
yer alma durumu* & 343 & 76.90 \\
Evet & 103 & 23.10 \\
Hayır & & \\
& &
\end{tabular}

\begin{tabular}{lll}
\hline İlişkili faktörler & & \\
Var & 157 & 35.20 \\
Yok & 289 & 64.80
\end{tabular}

\begin{tabular}{lrr}
\hline İlişkili faktörler** & & \\
Uygun & 151 & 96.20 \\
Uygun değil & 6 & 3.80 \\
& & \\
\hline Tanımlayıcı özellikler & 328 & 73.54 \\
Gerekli & 118 & 26.46 \\
Gerekli değil & & \\
\hline Tanımlayıcı özellikler*** & 44 & 13.41 \\
Var & 284 & 85.59 \\
Yok & & \\
\hline Tanımlayıcı özellikler & & \\
Uygun & 43 & 97.72 \\
Uygun değil & 1 & 2.28 \\
& & \\
\hline
\end{tabular}

$*_{n=446}$ üzerinden hesaplanmıștır

$* * n=157$ üzerinden hesaplanmiştı

$* * * n=328$ üzerinden hesaplanmıştır.

\section{Tartışma}

Hemşirelik tanılamasının doğru bir şekilde yapılması hasta sorunlarının belirlenmesini ve verilecek bakımın hızlı bir şekilde planlamasını sağlayarak hemşirelik bakımın kalitesini arttırır (Rabelo-Silva ve ark., 2020). Bu araştırma hemşirelik intörn öğrencilerinin COVID-19 şüpheli çocuk hasta için belirledikleri hemşirelik tanıların hasta için uygun olup olmadığını ve tanı yapısında 
gerekli özelliklerin yazılıp yazılmadığını incelemek amacıyla yürütülmüştür.

Tablo 3. Öğrencilerin COVID-19 şüpheli pediatrik hasta için belirledikleri NANDA sinıflandırma sisteminde yer alan hemşirelik tanıları $(\mathrm{n}=343)$

\begin{tabular}{|c|c|c|c|}
\hline Alanlar & Hemșirelik tanısı & $\mathbf{n}$ & $\%$ \\
\hline $\begin{array}{l}\text { Sağlığın } \\
\text { Yükseltilmesi }\end{array}$ & $\begin{array}{l}\text { Eğlence aktivitelerine } \\
\text { katılımda azalma }\end{array}$ & 2 & 0.58 \\
\hline \multirow[t]{5}{*}{ Beslenme } & Beslenmede değişim & 2 & 0.58 \\
\hline & Sıv1 volüm eksikliği & 4 & 1.17 \\
\hline & Elektrolit dengesizliği riski & 5 & 1.46 \\
\hline & Gereksinimden az beslenme & 3 & 0.88 \\
\hline & Sıv1 volüm eksikliği riski & 2 & 0.58 \\
\hline $\begin{array}{l}\text { Boşaltım ve } \\
\text { Gaz Değişimi }\end{array}$ & Gaz değişiminde bozulma & 23 & 6.71 \\
\hline \multirow{7}{*}{$\begin{array}{l}\text { Aktivite/ } \\
\text { Dinlenme }\end{array}$} & Uyku örüntüsünde bozulma & 9 & 2.62 \\
\hline & Yorgunluk & 5 & 1.46 \\
\hline & Aktivite intoleransı & 11 & 3.21 \\
\hline & Etkisiz solunum örüntüleri & 50 & 14.58 \\
\hline & $\begin{array}{l}\text { Spontene ventilasyonu } \\
\text { sürdürmede yetersizlik }\end{array}$ & 7 & 2.04 \\
\hline & Bilgi eksikliği & 19 & 5.54 \\
\hline & $\begin{array}{l}\text { Bilgi düzeyini } \\
\text { güçlendirmeye hazır oluş }\end{array}$ & 1 & 0.29 \\
\hline Kendini algılama & Beden imgesinde rahatsızlık & 1 & 0.29 \\
\hline \multirow[t]{4}{*}{ Rol ilişkileri } & $\begin{array}{l}\text { Aile içi süreçlerin } \\
\text { devamlılığında bozulma }\end{array}$ & 12 & 3.50 \\
\hline & $\begin{array}{l}\text { Aile içi süreçlerde } \\
\text { güçlenmeye hazır oluş }\end{array}$ & 2 & 0.58 \\
\hline & $\begin{array}{l}\text { Sosyal etkileşimde } \\
\text { bozulma, }\end{array}$ & 2 & 0.58 \\
\hline & $\begin{array}{l}\text { Ebeveyn çocuk bağlılığında } \\
\text { bozulma riski }\end{array}$ & 2 & 0.58 \\
\hline \multirow{8}{*}{$\begin{array}{l}\text { Baş etme/ } \\
\text { stres toleransı }\end{array}$} & Anksiyete & 22 & 6,41 \\
\hline & $\begin{array}{l}\text { Aile baş etmesinde } \\
\text { yetersizlik }\end{array}$ & 2 & 0.58 \\
\hline & $\begin{array}{l}\text { Aile başetmesi- } \\
\text { güçlendirmeye hazır oluş }\end{array}$ & 4 & 1.17 \\
\hline & $\begin{array}{l}\text { Bireysel başetmede } \\
\text { yetersizlik }\end{array}$ & 7 & 2.04 \\
\hline & Ölüm anksiyetesi & 8 & 2.33 \\
\hline & Korku & 16 & 4.67 \\
\hline & $\begin{array}{l}\text { Dayanma Gücünde } \\
\text { bozulma riski }\end{array}$ & 1 & 0.29 \\
\hline & Stres yüklenmesi & 1 & 0.29 \\
\hline \multirow{9}{*}{$\begin{array}{l}\text { Güvenlik/ } \\
\text { Korunma }\end{array}$} & Enfeksiyon riski & 27 & 7.87 \\
\hline & $\begin{array}{l}\text { Havayolunu temizlemede } \\
\text { yetersizlik }\end{array}$ & 8 & 2.33 \\
\hline & $\begin{array}{l}\text { Oral mukoz membranda } \\
\text { bozulma riski }\end{array}$ & 1 & 0.29 \\
\hline & $\begin{array}{l}\text { Deri bütünlüğünde bozulma } \\
\text { riski }\end{array}$ & 1 & 0.29 \\
\hline & Şok riski & 1 & 0.29 \\
\hline & Travma riski & 1 & 0.29 \\
\hline & Hipertermi & 51 & 14.87 \\
\hline & Kontaminasyon riski & 1 & 0.29 \\
\hline & Etkisiz doku perfüzyonu & 1 & 0.29 \\
\hline \multirow[t]{4}{*}{ Konfor } & Rahatta/konforda bozulma & 3 & 0.88 \\
\hline & Akut ağrı & 3 & 0.88 \\
\hline & Yalnızlık riski & 3 & 0.88 \\
\hline & Sosyal izolasyon & 15 & 4.37 \\
\hline $\begin{array}{l}\text { Büyüme ve } \\
\text { Gelişme }\end{array}$ & $\begin{array}{l}\text { Büyüme ve gelişmede } \\
\text { gecikme riski }\end{array}$ & 4 & 1.17 \\
\hline
\end{tabular}

Tablo 4. Öğrencilerin COVID-19 şüpheli pediatrik hasta için belirledikleri NANDA sinıflandırma sisteminde yer almayan hemşirelik tanıları $(n=103)$

\begin{tabular}{lrr}
\hline Hemşirelik tanısı & n & \% \\
\hline Enfeksiyon bulaştırma riski & 48 & 46.60 \\
Enfeksiyon & 23 & 22.33 \\
Solunum fonksiyonunda & 8 & 7.77 \\
bozulma riski & & \\
Hava yolları açıklı̆̆ında & 5 & 4.86 \\
yetersizlik & & \\
Sağlığı etkisiz yönetme riski & 4 & 3.89 \\
Hipoksi & 2 & 1.94 \\
Bağışılık sistemini & 2 & 1.94 \\
güçlendirmeye hazır oluş & & \\
Beslenmede dengesizlik riski & 2 & 1.94 \\
Gaz alışverişinde bozulma riski & 2 & 1.94 \\
Rahatta/konforda bozulma riski & 1 & 0.97 \\
Anksiyete riski & 1 & 0.97 \\
Covid semptomları ile Baş & 1 & 0.97 \\
edememe riski & & \\
Uyku düzeninde bozulma riski & 1 & 0.97 \\
Aile başetmesinde etkisizlik & 1 & 0.97 \\
riski & & \\
Sosyal izolasyon riski & 1 & 0.97 \\
Aile içi süreçlerin \\
devamlılığında bozulma riski
\end{tabular}

Araştırmada öğrencilerin çoğunlukla belirledikleri tanılardan birincisi hipertermidir (Tablo 3). Çocuklar COVID-19'u çoğunlukla hafif semptomlarla geçirmesine rağmen ateş veya pnömoni varlığ 1 prognozu kötüleştirmektedir. Vakaların çoğu enfeksiyon başladıktan 1-2 hafta sonra iyileşmesine rağmen bazı vakalarda alt solunum yolu enfeksiyonları izlenebilmektedir. $\mathrm{Bu}$ nedenle bu iki haftalık süreçte COVID-19 tanısı olan çocuğun ateş yönetimi oldukça önemlidir (Shen ve ark., 2020; Keklik ve ark. 2020). Çalışmada da ateş öğrencilere verilen örnek vakadaki hasta bulgularından olduğuna göre, öğrencilerin belirlediği hipertermi tanısının COVID-19 şüpheli çocuk hasta için uygun olduğu görülmektedir.

Etkisiz solunum örüntüleri hemşirelik tanısı, solunum şeklinde bir değişim nedeniyle yeterli ventilasyonu sağlayamayan ya da sağlayamama potansiyeli bulunan bir bireydeki durumu anlatan hemşirelik tanısıdır (Carpenito-Moyet, 2012). Literatürde COVID-19'un siklıkla solunum sistemini etkilediği bildirilmiştir (She ve ark., 2020a; Lu ve Shi, 2020; Ludvigsson, 2020). Yine araştırmada verilen hasta bulguları arasında da 
öksürük ve solunum sıkıntısı vardır. Nitekim öğrencilerin çoğunlukla koyduğu tanılardan ikinci sırada etkisiz solunum örüntüleri tanısının yer almaktadır.

Bununla birlikte öğrencilerin çoğunlukla koydukları hemşirelik tanılarından bir diğeri de gaz değişiminde bozulmadır (Tablo 3). Gaz değişiminde bozulma hemşirelik tanısı, aktif dispne veya solunum çabasında artma belirtisi gösteren bireydeki akciğer alveolleri ve vasküler sistem arasındaki gaz geçişinde mevcut ya da potansiyel azalma durumu ifade etmektedir (Carpenito-Moyet, 2012). Bu durum bu iki hemşirelik tanısının da COVID-19 hastası için uygun olduğunu göstermektedir.

COVID-19 şüpheli ya da pozitif olan bireyler izole edilmektedir (World Health Organization, 2020). Belirsizlik ve özgürlük kaybına neden olan izolasyon süreci (izolasyon odası, yoğun bakım ünitesi veya evde izolasyon gibi) strese neden olabilmekte, kaygı ve korku gibi diğer bazı olumsuz duyguları tetikleyebilmektedir (Orru ve ark., 2020). Benzer olarak öğrencilerin çoğunlukla koyduğu tanılardan olan anksiyete tanıs1; belirsizlik, spesifik olmayan bir tehdide karşı otonom sinir sistemi aktive olan ve huzursuzluk yaşayan birey veya grup için uygun hemşirelik tanısidır (Carpenito-Moyet, 2012), ve COVID-19 şüpheli hasta ve ailesi için uygundur (Tablo 3).

Pediatri hemşireliğinde yer alan önemli kavramlardan birisi de aile merkezli bakımdır (Öztürk ve Ayar, 2014). Öğrencilerin belirlediği aile süreçlerin devamlılığında bozulma, ebeveyn çocuk bağlılığında bozulma riski tanıları da öğrencilerin hasta çocuğun hemşirelik bakımına aileyi de dahil ettiklerini göstermektedir (Tablo 3).

Öğrencilerin NANDA sınıflandırma sisteminde olmayan tanılardan en sik koydukları hemşirelik tanılarından birincisi enfeksiyon bulaştırma riskidir (Tablo 4). Enfeksiyon bulaştırma riski patojen ya da firsatçı bir ajanı başkalarına geçirme/bulaştırma riski taşıyan bireydeki durumu göstermektedir (Carpenito-Moyet, 2012). Covid-19 öksürme, hapşırma, konuşmayla yayılan damlacıkların solunmas1 veya virüs bulunan yüzeylere dokunduktan sonra ellerin burun, ağız ve göze götürülmesi yoluyla bulaşmaktadır (Centers for Disease Control and Prevention, 2020; T.C. Sağlik Bakanlığı 2020). T.C. Sağlık Bakanlığı (2020) ve Dünya Sağlık Örgütü (2020) Covid-19 pozitif veya şüpheli hasta ile temas durumunda standart, damlacik ve temas izolasyon önlemlerini önermektedir. Ancak hastanın sekresyonları veya vücut çıkartılarının aerosolizasyonuna neden olabilecek durumlarda (trakeal entübasyon ve ekstübasyon, noninvaziv ventilasyon, bronkoskopi, yüksek akım oksijen uygulamak, nebülizatör ile tedavi uygulama gibi) solunum izolasyon önlemlerinin de alınmasını önerilmektedirler (World Health Organization, 2020; T.C. Sağlık Bakanlığı, 2020). Bu bilgiler doğrultusunda enfeksiyon bulaştırma riski hemşirelik tanıs1, COVID-19 pozitif veya şüpheli hasta için uygun bir tanıdir.

$\mathrm{Bu}$ araştırmada hemşirelik öğrencilerinin COVID-19 şüpheli pediatrik hasta için uygun tanıları belirleyebilmişlerdir. Araştırmanın verileri uzaktan eğitim sırasında online yürütülmüştür. COVID-19 pandemisinin yayılma hızını yavaşlatmak için pek çok ülkede eğitim kurumlarının geçici süre ile kapatılmasına karar verilmiştir. Türkiye'de de görülen ilk COVID-19 olgusunun 11 Mart 2020 tarihinde Sağlık Bakanlığ tarafından açıklanması ile tüm eğitim kurumlarında uzaktan eğitime geçilmiştir (Yükseköğretim Kurulu 2020). Uzaktan eğitimin başarıs1 teknolojiye bağlıdır; teknik donanım, bağlantı hızı gibi özellikler öğrencinin derse odaklanmasını engelleyebilir. Diğer yandan web tabanlı eğitim zaman ve fiziksel mesafeden bağımsız olarak öğrencinin kendi öğrenme hızına göre ilerleyebilmesini sağlamaktadır. $\mathrm{Bu}$ durunda bireyselleştirilmiş öğrenmeyi sağlamaktadır (Wasim ve ark., 2014). Bununla birlikte web tabanlı eğitimin eleştirel düşünmeyi desteklediği bildirilmiștir (Richardson ve ark., 2017). Basit ve Korkmaz (2020) web tabanlı eğitimin hemşirelik son sınıf ögrencilerinin bakım planı hazırlama becerilerinin kolaylaştırdığını saptamışlardır (Basit ve Korkmaz, 2020). Yapılan araștırmada da hemşirelik öğrencilerinin uzaktan eğitim sırasında kendi kendine öğrenme ve literatür tarama becerilerini kullanarak örnek vakayı eleştirel olarak analiz ettikleri düşünülmektedir.

\section{Sonuç ve Öneriler}

Araştırmada hemşirelik intörn öğrencilerinin COVID-19 şüpheli çocuk hasta için uygun hemşirelik tanılarını belirleyebildikleri görülmüştür. Ancak araştırma bulgularına göre bir hemşirelik tanısında yer alması gereken özellikler (ilişkili faktör ve tanımlayıcı özellikler) konusunda öğrencilerin belirlediği tanılarda yetersizlikler bulunmuştur. $\mathrm{Bu}$ nedenle hemşirelerin tanıları ve hemşirelik tanılama sistemleri ile ilgili intörn öğrencilere eğitim verilmesi önerilmektedir. 
Bununla birlikte hemşirelik süreci ile ilgili konulara müfredatta daha fazla yer verilmesi hem klinik uygulamalarda hem de teorik derslerde çok sayıda vaka üzerinden öğrencilere hemşirelik süreci uygulama firsatı sağlanmalıdır.

\section{Araştırmanın Etik Yönü/ Ethics Committee Approval: Pamukkale Üniversitesi Tıp Fakültesi Girişimsel Olmayan Klinik Uygulamalar Etik Kurulundan (10 Haziran 2020 tarih ve 60116787- 020/34110 sayı) onay alınmıştır.}

Hakem/Peer-review: Diş hakem değerlendirmesi

Yazar Katkısı/Author Contributions: Fikir/kavram: SSC, TT; Tasarım: SSC, TT; Danışmanlık: SSC, TT; Veri toplama ve/veya Veri İşleme: SSC, ÇE; Analiz ve/veya Yorum: SSC, TT; Kaynak tarama; SSC, ÇE; Makalenin Yazımı: SSC; Eleştirel inceleme: TT.

Çıkar çatışması/Conflict of interest: Yazarlar tarafından çıkar çatışması bildirilmemiştir.

Finansal Destek/Financial Disclosure: Bu araştırmanın yürütülmesi için finansal destek alınmamıştır.

\section{Çalışma Literatüre Ne Kattı?}

- Araştırmada hemşirelik öğrencilerinin COVID-19 şüpheli çocuk hastanın var olan ve olası problemlerini saptayabildikleri belirlenmiştir.

- Öğrencilerin hemşirelik tanı yapısında yer alan ilişkili faktör, tanımlayıcı özellikler gibi unsurları belirlemede sorun yaşadıkları belirlenmiştir.

- Araştırmada literatürde ve araştırma bulgularında yer alan hemşirelik tanılarının, COVID-19'lu çocuk hastaların bakımında hemşirelere ve öğrencilere yol gösterebileceği düşünülmektedir.

\section{Kaynaklar}

Ak, B. (2013). Hemşirelik Süreci. Conk, Z, Başbakkal, $\mathrm{Z}$, Bal Yılmaz, H, Bolışık B, editors. Pediatri Hemşireliği. İzmir: Akademisyen Tıp Kitapevi, s.937-968.

Akoğlu G, Karaaslan BT. (2020). COVID-19 ve izolasyon sürecinin çocuklar üzerindeki olas1 psikososyal etkileri. İzmir Katip Çelebi Üniversitesi Sağlık Bilimleri Fakültesi Dergisi, 5(2), 99-103.

Bahçecioğlu Turan G, Tan M, Dayapoğlu N. (2017). Hemşirelik öğrencilerinin ve klinik hemşirelerin intörn uygulamasına ilişkin görüşlerinin belirlenmesi. Anadolu Hemşirelik ve Sağlık Bilimleri Dergisi, 20, 170-179.

Basit G, Korkmaz F. (2020). The effect of web-based nursing process teaching on senior nursing students' care planning skills. International Journal of Nursing Knowledge, 32(1), 4-19.
Bialek S, Gierke R, Hughes M, McNamara LA, Pilishvili T, Skoff T. (2020) Coronavirus Disease 2019 in Children (United States, February 12-April 2, 2020). MMWR, 69(14), 422-426.

Birol L. (2013). Hemşirelik Süreci: Hemşirelik Bakımında Sistematik Yaklaşım. 10. Baskı, İzmir, Berke Ofset Matbaacilık, s. 158-170.

Cao O, Chen Y, Chen C, Chiu C. (2020). SARS-CoV-2 infection in children: transmission dynamics and clinical Characteristics. Journal of the Formosan Medical Association, 119, 670-673.

Carpenito-Moyet LJ. (2012) Hemşirelik Tanıları El kitabı. Çeviren: Firdevs Erdemir. 13. Bask1, İstanbul, Nobel Tip Kitapevleri, s. 1-10.

Centers for Disease Control and Prevention (CDC). (2020) Information for pediatric healthcare providers. Erişim tarihi: 19 Aralı, 2020, https://www.cdc.gov $\quad$ /coronavirus/2019ncov/hcp/pediatric-hcp.html.

González-Aguña A, Jiménez-Rodríguez ML, Fernández-Batalla M, Herrero-Jaén S, Monsalvo-San Macario E, Real-Martínez V ve ark. (2020). Nursing Diagnoses for Coronavirus Disease, COVID-19: Identification by Taxonomic Triangulation. International Journal of Nursing Knowledge, 32(1), 59-67. https://doi.org/10.1111/2047-3095.12301

Hagmann, SHF. (2020). COVID-19 in children: More than meets the eye. Travel Medicine and Infectious Disease, 34, 101649. https://doi.org/10.1016/j.tmaid.2020.101649

Hakverdioğlu Yönt G, Korhan EA, Erdemir F, Müller-Staub M. (2014). Nursing diagnoses determined by first year students: A vignette study. International Journal of Nursing Knowledge, 25(1), 39-42.

Huang C, Wang Y, Li X, Ren L, Zhao J, Hu Y ve ark. (2020). Clinical features of patients infected with 2019 novel coronavirus in Wuhan, China. The Lancet, 395(10223), 497-506. http://doi.org/10.1016/S0140-6736(20)30183-5

Keklik S, Karakul A, Özgüven Öztornacı B, Ardahan E, Doğan P, Doğan Z ve ark. (2020). COVID-19 tanıs1 olan çocuk hastalarda ateş yönetimi. İzmir Katip Çelebi Üniversitesi Sağlık Bilimleri Fakültesi Dergisi, 5(2), 123-128.

Keski Ç, Karadağ A. (2010). Hemşirelik son sınıf öğrencilerinin hemşirelik süreci hakkındaki bilgi düzeylerinin incelenmesi. Hemşirelikte Araştırma Geliştirme Dergisi, 12(1), 41-52.

Lu Q, Shi Y. (2020). Coronavirus disease (COVID-19) and neonate: What neonatologist need to know. Journal of Medical Virology, 92(6), 564-567.

Ludvigsson, JF. (2020). Systematic review of COVID-19 in children shows milder cases and a better prognosis than adults. Acta Paediatrica, 109 (6), 1088-1095.

Moorhead S, Macieira TGR, Lopez KD, Mantovani VM, Swanson E, Wagner C ve ark. (2021). NANDA-I, NOC, and NIC Linkages to SARS-Cov-2 
(Covid-19): Part 1. Community Response. International Journal of Nursing Knowledge, 32(2), 59-67.

https://doi.org/10.1111/2047- 3095.12291.

Orru G, Ciacchini R, Gemignani A, Conversano C. (2020). Psychological intervention measures during the COVID-19 pandemic. Clinical Neuropsychiatry, 17(2), 76-79.

Öztürk C, Ayar D. (2014). Pediatri hemşireliğinde aile merkezli bakım. Dokuz Eylül Üniversitesi Hemşirelik Fakültesi Elektronik Dergisi, 7(4), 315320.

Özveren H, Özden D, Gülnar E. (2019). Determination of nursing students' perception states in nursing diagnosis. International Journal of Caring Sciences, 12(2), 1049-1055.

Pars H. (2020) COVID-19 pandemisinde çocuklar ve pediatri hemşiresinin rolleri. Hacettepe Üniversitesi Hemşirelik Fakültesi Dergisi, 7(Özel Sayı): 66-75.

Popil I. (2011). Promotion of critical thinking by using case studies as teaching method. Nurse Education Today, 31(2), 204-207

Queiroz AGS, de Souza RZ, Sottocornola SF, Barbosa SJ, Pinheiro FA, de Souza LP. (2020). Diagnósticos de enfermagem segundo a taxonomia da NANDA internacional para sistematização da assistência de enfermagem a COVID-19. Journal of Health \& Biological Sciences, 8(1), 1-6.

Rabelo-Silva ER, Monteiro Mantovani V, López Pedraza L, Cardoso PC, Takao Lopes C, Herdman TH. (2020). International Collaboration and New Research Evidence on Nanda International Terminology. International Journal of Nursing Knowledge. Ahead of prints. https://doi.org/10.1111/2047-3095.12300

Richardson JC, Maeda Y, Lv J, Caskurlu S. (2017). Social presence in relation to students' satisfaction and learning in the online environment: A metaanalysis. Computers in Human Behavior, 71, 402417.

She J, Jiang J, Ye L, Hu L, Bai C, Song Y. (2020a). 2019 novel coronavirus of pneumonia in Wuhan, China: Emerging attack and management strategies. Clinical and Translational Medicine, 9(1), 1-7. http://doi.org/10.1186/s40169-020-00271-z

She J, Liu L, Liu W. (2020b). COVID-19 epidemic: disease characteristics in children. Journal of medical virology, 92, 747-754.

Shen KL, Yang YH, Jiang RM, Wang TY, Zhao DC, Jiang Y ve ark. (2020). Updated diagnosis, treatment and prevention of COVID-19 in children: experts' consensus statement (condensed version of the second edition). World Journal of Pediatrics, 1-8.

Sukmana M, Yuniarti FA. (2020). The pathogenesis characteristics and symptom of Covid-19 in the context of establishing a nursing diagnosis. Jurnal Kesehatan Pasak Bumi Kalimantan, 3(1), 21-28.

Swanson E, Mantovani VM, Wagner C, Moorhead S, Lopez KD, Macieira TGR ve ark. (2020).
NANDA-I, NOC, and NIC linkages to SARS-CoV-2 (COVID-19): Part 2. Individual response. International journal of nursing knowledge. 32(1), 68-83. https://doi.org/10.1111/2047-3095.12307

Şendir M, Acaroğlu R, Aktaş A. (2014). Hemşirelik yüksekokulu son sınıf öğrencilerinin hemşirelik sürecine ilişkin bilgi ve görüşleri. Florence Nightingale Hemşirelik Dergisi, 17(3), 166-173.

T.C. Sağlık Bakanlığı (2020). Covid-19 Bilgilendirme Sayfası. Erişim tarihi: Haziran 2020 https://covid19.saglik.gov.tr/TR-66125/sikcasorulan-sorular-halka-yonelik.html.

Türk Hemşireler Derneği. Hemşirelik Kanunu. (02.05.2007). Erişim tarihi: Haziran 2020 http://www.turkhemsirelerdernegi.org.tr/tr/yasa-veyonetmelikler/yasa/hemsirelik-kanunu.aspx.

Türk Hemşireler Derneği. (2020). COVID-19 özel sayısı. Erişim tarihi: Mayıs 2020 https://www.thder.org.tr

Wasim J, Sharma SK, Khan IA, Siddiqui J. (2014) Web based learning. International Journal of Computer Science and Information Technologies, 5, 446-449.

World Health Organization. (2009). Lemon Learning Material on Nursing. Chapter 4: Nursing Process and Documentation. Erişim tarihi: Haziran 2020 http://www.who.int/topics/nursing/en/.

World Health Organization. Infection prevention and control during health care when novel coronavirus $(\mathrm{nCoV})$ infection is suspected. January 25, 2020. Erişim tarihi: Şubat 2020 https://www.who.int/publications-detail/infectionprevention-and-control-during-health-carewhennovel-coronavirus-(ncov)-infection-is-suspected20200125

Yılmaz AA, Gençer E, Seçkin Ç, Yılmaz H, Güven KT, Gözütok S. (2019). Hemşirelik öğrencilerinin hemşirelik sürecinin veri toplama aşamasına ilişkin görüşleri ve yaşadıkları güçlükler. Anadolu Hemşirelik ve Sağlık Bilimleri Dergisi, 22(4), 231239.

Yükseköğretim Kurulu (YÖK) (2020). Basın açıklaması. Erişim tarihi: Mayıs 2020 https://www.yok. gov.tr/Sayfalar/Haberler/2020/ 